\title{
Apontamentos sobre Poder, Autoridade e Ascetismo: uma breve comparação entre Agostinho e João Cassiano
}

Rossana Pinheiro*

Universidade Federal de Alagoas

\section{Resumo}

O presente artigo tem o intuito de discorrer sobre as concepções de "poder", "autoridade" e ascetismo de dois importantes autores cristãos do século V: Agostinho de Hipona e João Cassiano de Marselha. Para tanto, partimos de estudos contemporâneos acerca do tema, tais quais os de Max Weber e Hannah Arendt, dois nomes fundamentais na investigação sobre uma temática que tem estimulado produções de pesquisas nas áreas da História, Filosofia e Sociologia desde finais do século XIX.

Palavras-chave: poder, autoridade, ascetismo, cristianismo, Agostinho de Hipona, João Cassiano.

\section{Abstract}

This article is about the conceptions of power, authority and ascetism of two important christians' authors from the V century: Augustin of Hippo and John Cassian. As a starting point for this study, we used the works of Max Weber and Hannah Arendt, two fundamental names in the studies of a subject that has been stimulating historian, philosophian and sociologican production since the end of the XIX century.

Keywords: power, authority, christianism, asceticism, Augustin of Hipo, Jean Cassian.

\section{Apresentação do problema:}

O estudo sobre poder e autoridade tem sido uma preocupação recorrente das ciências sociais e da filosofia política. Determinar a relação que se estabelece entre indivíduo e sociedade em termos de dominação e obediência motivou teses e investigações entre os mais célebres pensadores das ciências sociais desde seu nascedouro no século XIX até boa parte do século XX. Estes trabalhos serviram de estímulos teóricos às produções historiográficas, e dentre elas, àquelas voltadas à compreensão do período marcado pela ascensão da Igreja, bem como pela ausência de um Estado burocrático e capitalista. Neste âmbito, destacam-se, fundamentalmente, as reflexões de Max Weber e Hannah Arendt, por exemplo, que forneceram um aparato conceitual historicamente delimitado para a compreensão de tal problemática desde a Antigüidade até o período pós-guerra.

Na obra clássica Economia e sociedade, Max Weber apresentou sua teoria da dominação e definiu o que é autoridade a partir de três formas de expressão - carismática, tradicional e legal. Segundo ele, poder era a

\footnotetext{
* Professora efetiva do Departamento de Filosofia da Universidade Federal de Alagoas. Mestre em História pela UNESP de Franca e Doutoranda em História pela UNICAMP.
} 
probabilidade de imposição da vontade a outrem enquanto autoridade era a probabilidade de encontrar obediência'. Pelo fato de a sociologia ser uma ciência preocupada com a ação social - ações com intencionalidade e medidas por meio das respostas provocadas e visíveis no comportamento alheio autoridade ou dominação seria, para o autor, muito mais plausível de ser investigada no curso das pesquisas sociológicas. Dois elementos nos interessam nesta conceituação de Weber. O primeiro é que mesmo ao insistir que suas categorias de análise eram tipológicas, ou seja, sem relação direta com a realidade, ele, além de situá-las em ambientes históricos determinados, foi fonte conceitual de autores da filosofia política e de historiadores para compreender o sistema político medieval e, principalmente, feudal, o qual, por carecer de uma estrutura estatal centralizada, teria sido, por muito tempo, considerado anárquico. O segundo e principal ponto de interesse está na associação entre dominação e autoridade, de um lado, e a distinção entre ambas e poder, de outro.

Tal diferença está na base dos estudos de Hannah Arendt, por exemplo, que investiga tais relações durante o período de queda do Império Romano, que aqui nos interessa. O ponto de partida de Arendt é a crise moderna da autoridade, tanto no âmbito político quanto no das reflexões filosóficas. Ao lidar com a questão, a autora inverte a ótica otimista de Weber e enfatiza a falência da racionalidade do Estado burocrático legal face à emergência de regimes totalitários. É a partir deste cenário que Arendt situa sua investigação sobre as noções de autoridade e poder, em correlação com a liberdade.

A autora trata a autoridade em relação à obediência, como o fizera Weber, acentua a própria hierarquia como elo comum entre aqueles que mandam e os que obedecem, e a exclui da esfera dos meios externos de coerção. Se a autoridade não foi poder e violência, também não foi persuasão, que pressupõe igualdade e argumentos. Da mesma forma, ela não foi tirania, totalitarismo ou ditadura. Segundo a autora, desde o século XIX, liberais e conservadores lidaram com a questão da autoridade em associação a um progresso ou regresso na liberdade. Em ambas as concepções políticas, não

\footnotetext{
1 "Poder significa toda probabilidade de impor a própria vontade numa relação social, mesmo contra resistências, seja qual for o fundamento dessa probabilidade. Dominação [autoridade] é a probabilidade de encontrar obediência a uma ordem de determinado conteúdo, entre determinadas pessoas indicáveis". MAX WEBER. Conceitos sociológicos fundamentais. Lisboa: Edições 70, 2005, p. 21.
} 
havia a preocupação em se estabelecer a distinção entre formas de governo e sua relação com a liberdade. Neste aspecto, as diferenças entre autoridade, totalitarismo e ditadura eram minimizadas, ou mesmo tidas como inexistentes. Todavia, o regime autoritário caracterizava-se pela referência às leis que garantiam a liberdade dos subordinados ${ }^{2}$, e também lhe conferiam uma fonte de força externa e considerada superior.

Isto teria aparecido, primeiramente, com Platão, que havia tentado formular uma expressão intelectual acerca da autoridade ${ }^{3}$, na qual as idéias e leis tornaram-se as medidas e parâmetros irrepreensíveis para gerar a obediência da comunidade. Somente a República Romana teria revestido a autoridade com uma experiência política própria e lançado as bases de sua perenidade ao afirmar, por um lado, a vinculação da autoridade com a tradição e, por outro, com a religião. A autoridade do Senado Romano estava assentada na dependência e na aceitação da força coercitiva do passado sobre o presente, uma vez que o cerne da vida política romana, desde a República até o final do Império, era a idéia da sacralidade da fundação da cidade de Roma. Desta forma, participar da política significava preservar, reproduzir e aumentar esta fundação original e singular, estabelecendo um crescimento rumo ao passado, que se tornava santificado através da tradição.

Neste contexto, o termo auctoritas teria surgido e fora atribuído àqueles que tinham por meta aumentar a fundação, como os anciãos, o Senado e os patres, e que haviam obtido tal autoridade por descendência e transmissão. Esta fora a noção herdada pela Igreja, mas com a modificação do marco histórico fundamental que determinava os modelos e padrões aceitos e consagrados, na medida em que a fundação de Roma cedeu lugar à vida, morte e ressurreição de Cristo. Além desta modificação promovida na definição de autoridade romana, a Igreja incorporou a Filosofia Grega, promovendo uma junção entre autoridade baseada em um princípio historicamente situado e a noção de medidas e regras transcendentes que determinavam padrões

\footnotetext{
2 "Autoridade implica uma obediência na qual os homens retêm sua liberdade". ARENDT, Hannah. Entre o passado e o futuro. São Paulo: Perspectiva, 2005, p. 144.

${ }^{3}$ Apenas intelectual na medida em que a Grécia não conheceu nem o termo "autoridade" e tampouco uma forma de governo do tipo autoritária: "As grandiosas tentativas da Filosofia grega para encontrar um conceito de autoridade que obstasse a deterioração da polis e salvaguardasse a vida do filósofo soçobraram devido ao fato de não existir, no âmbito da vida política grega, nenhuma consciência de autoridade que se baseasse em experiências políticas imediatas". Ibid, p. 161.
} 
universais de conduta e reforçavam a obediência legítima. Segundo Arendt, Agostinho teria consolidado o tipo de governo autoritário da lgreja, e teria levado adiante a distinção entre poder e autoridade ${ }^{4}$ existente ao longo do Império Romano:

O sinal mais claro dessa continuidade talvez seja o fato de a Igreja, ao se atirar em sua grande carreira política no século $\mathrm{V}$, ter adotado imediatamente a distinção romana entre autoridade e poder, reclamando para si mesma a antiga autoridade do senado e deixando o poder - que no Império Romano não estava mais nas mãos do povo, tendo sido monopolizado pela família imperial - aos príncipes do mundo (ARENDT, 2005, p. 169).

Ainda que o olhar apurado da filósofa demonstre a importância e a atualidade deste tema, seu estudo acerca do século $V$ foi condicionado por suas experiências políticas e pelas reflexões delas decorrentes. A autora defendia que tal dissociação entre poder e autoridade fora acompanhada pela privatização do poder público e pelo inchaço do privado. Foi nas obras $A$ condição humana ${ }^{5}$ e 0 que é liberdade ${ }^{6}$, que desenvolveu sua tese de que durante a Idade Média a emergência da liberdade interior e a defesa de virtudes como a humildade e a mansidão tornaram inviáveis à existência de uma esfera pública. O Baixo Império Romano, ao retirar do cidadão sua liberdade efetiva, teria propiciado um terreno fértil para o desabrochar da reflexão metafísica acerca da liberdade, ocasionando uma dissociação também entre política e liberdade. Se durante a Antiguidade, a liberdade não figurava entre as questões filosóficas porque era uma realidade e a própria condição do exercício político, com o impedimento da ação e do discurso no cenário

\footnotetext{
4 "A autoridade, em contraposição ao poder (potesta) tinha suas raízes no passado, mas esse passado não era menos presente na vida real da cidade que o poder e a força dos vivos" e ainda "A característica mais proeminente dos que detêm autoridade é não possuir poder". Ibid, p. 164. Parece-nos que para Arendt, a autoridade gerava obediência sem recorrer ao uso da violência pelo fato de que era uma força derivativa e referenciada naqueles 'mortos especiais', fundadores da cidade de Roma, enquanto poder era próprio ao comando daqueles que ainda estavam vivos. Esta distinção marcou a interpretação que se faz da Antigüidade Tardia, principalmente a partir do século VI, com base nos dispositivos do Papa Gelásio. Um exemplo desta retomada entre os historiadores pode ser encontrado em Larry Scanlon, para quem havia na Idade Média uma distinção fundamental entre "poder" e "autoridade" decorrente do fato de que tinha auctoritas quem não possuía potesta, e esta se caracterizava pelo exercício cotidiano da gestão administrativa. Veremos adiante que esta relação entre ausência que evoca uma existência, de fato, pode ser encontrada na obra de Cassiano, mas por meio de um elemento mais sutil e menos "administrativo" do que o postulado pelos nossos autores. SCANLON, Larry. "Auctoritas' and 'potestas': a model of analysis for medieval culture". Narrative, authority and power: the medieval exemplum and the Chaucerian tradition. Cambridge: Cambridge University Press, 1994.

${ }^{5}$ ARENDT, Hannah. "As esferas pública e privada". A condição humana. Rio de Janeiro: Forense Universitária, 1999.

${ }^{6}$ ARENDT, Hannah. "O que é liberdade". Entre o passado e o futuro. São Paulo: Perspectiva, 2005.
} 
público, ela se tornaria, no dizer de Arendt, o tema metafísico por excelência. Em certa medida, a discussão levada a cabo por ela, a propósito da relação entre autoridade e liberdade nas concepções liberais e conservadoras, teve seus desdobramentos em sua própria análise do século V.

Foi a partir da inquietação surgida com as afirmações dos autores apresentados acima sobre as relações entre poder e autoridade, tanto em sentido conceitual quanto historicamente determinado, que nos propusemos a investigar tais noções nas obras de dois importantes cristãos do século V: Agostinho de Hipona e João Cassiano de Marselha. Ambos desempenharam um papel fundamental na construção do pensamento cristão, por um lado, e na consolidação e institucionalização dos dois setores mais significativos da lgreja: o episcopado e o monacato. Agostinho foi bispo de Hipona, mas é conhecida sua admiração pelo movimento monástico iniciado no Egito com Antônio. Em suas Confissões, o autor diz que a leitura da Vida de Santo Antônio, escrita por Atanásio, foi determinante na sua conversão ao cristianismo. Ainda que ele não tenha se consagrado integralmente ao ofício monástico, produziu duas regras monásticas $^{7}$ e lutou por fazer com que os bispos seguissem pressupostos monásticos, como, por exemplo, a partilha da vida em comum, sob a autoridade de um só ${ }^{8}$. João Cassiano, por sua vez, não chegou ao episcopado, mas manteve relações estreitas com os bispos da Provença ${ }^{9}$. Suas obras marcam a preocupação com a institucionalização de um monacato, através da submissão à autoridade de um ancião, da partilha de bens e da meta de adquirir a pureza de coração.

Nossos autores estavam inseridos em um contexto de permissão, oficialização e incentivo ao cristianismo, sobretudo após a conversão de Constantino, e participaram de maneira intensa deste movimento. Foram, assim, como bispo e abade que se pronunciaram sobre as questões relativas ao poder e à autoridade em um momento em que o cristianismo passara de uma religião clandestina, com seus mártires, para a própria religião de um Império que se fragmentava politicamente. Ademais, tais noções são pensadas

\footnotetext{
7 Praeceptum e Ordo monasterii, escritas em 397 e 411. DE VOGÜÉ, Adalbert. Histoire littéraire du mouvement monastique: I'essor de La littérature lérinienne et les écrits contemporains (420-500). Paris: Cerf, 2003, v. VII.

8 LEYSER, Conrad. Authority and ascetism from Augustine to Gregory the Great. Oxford: Clarendon University Press, 2000.

${ }^{9}$ As dedicatórias das obras Instituições cenobíticas e Conferências de João Cassiano comprovam tais relações.
} 
por eles em correlação ao dado de fé cristão, geralmente designado por pecado original, e a queda humana, como bem salientou Michel Senellart ${ }^{10}$. O pecado original fazia com que o homem estivesse sujeito à coação e à necessidade de submissão a uma força externa a si mesmo que o reconduzisse e o obrigasse a fazer ou a deixar de fazer aquilo que ele deveria, sem ser capaz, em decorrência de uma vontade cindida. Esta deficiência na vontade humana promovia uma constante dissociação entre poder e querer, na medida em que o homem não fazia o que queria e não queria o que fazia. Em Adão, os homens teriam perdido a liberdade e haviam sido lançados na pior escravidão na medida em que, ao declarar a autonomia de sua vontade frente ao Criador, Adão nada mais havia feito do que lançar ao gênero humano a marca da heteronomia. A partir da queda, a vontade tornara-se inapta para comandar a carne, e isto exigia o emprego de coerção.

\section{Do pecado à República: Agostinho e A cidade de Deus contra os pagãos:}

Tal reflexão sobre o pecado como elemento inibidor do exercício do poder e a possibilidade de constituição de uma República cristã pode ser encontrada em dois momentos da obra $A$ cidade de Deus contra os pagãos de Agostinho: no livro XIV e no XIX. Escrita em 410 após o saque de Roma por Alarico, a obra testemunha o acirramento das disputas e polêmicas entre cristãos e pagãos, que diziam respeito à utilidade e eficácia do cristianismo na condução e fortalecimento do Império. A motivação direta de Agostinho para compô-la foi o recebimento da carta de Marcelino. Este cristão desejava saber qual era o posicionamento do bispo acerca das teses pagãs contrárias à cristianização do Império e à capacidade dos cristãos de o conduzirem. Os argumentos do pagão Volusiano, levados ao conhecimento de Agostinho por Marcelino, ressaltavam que a doutrina cristã incentivava a renúncia ao mundo e, desta forma, desviava os cidadãos dos serviços devidos ao Império. $O$ cristianismo também estava enraizado em virtudes que se contrapunham ao crescimento imperial como, por exemplo, a mansidão, a não retribuição do mal com mal, o dar a outra face, a humildade e o pacifismo. Outro argumento apontava que o destino de Roma sempre estivera atrelado ao culto de vários

10 SENELLART, Michel. As artes de governar. São Paulo: Editora 34, 2006. 
deuses. O saque de Roma era, portanto, um castigo imposto pelos deuses traídos aos homens traidores. Finalmente, era o próprio Marcelino quem apresentava o fato inegável de que fora após a conversão do Império ao cristianismo que o saque ocorrera ${ }^{11}$.

Agostinho fez de sua resposta às críticas dos pagãos uma obra capaz de inverter as acusações de que o cristianismo seria o responsável pela desagregação política romana e com isto afirmou seu papel central na reestruturação social e política do Império. A reflexão desenvolvida pelo bispo nesta obra trouxe mais do que respostas aos pagãos. Ela forneceu elementos para fundamentar as relações dos contemporâneos de Agostinho, bem como dos homens no decorrer do Ocidente medieval, tendo em vista que suas considerações sobre a caridade como vínculo social foram constantemente retomadas por teólogos cristãos, como, por exemplo, Pedro Lombardo e Tomás de Aquino ${ }^{12}$. A inversão que Agostinho fez das críticas pagãs e sua decorrente afirmação de que a desagregação romana ocorrera em virtude dos vícios dos próprios romanos foram confirmadas com a leitura dos escritores romanos. A partir deles, Agostinho comprovou que os vícios que levaram à derrocada do Império Romano já estavam latentes antes mesmo da cristianização e do saque de Roma. Nestas circunstâncias, o cristianismo contribuiria para a manutenção e fortalecimento de Roma, na medida em que obrigaria o cidadão a agir virtuosamente e a procurar a salvação da sociedade política como um todo. Com o cristianismo, aquilo que o cidadão deveria fazer por amor ao Império, deveria ser feito por amor a Deus ${ }^{13}$. Melhor seria, então, que o Império fosse comandado por cristãos.

No livro XIV, capítulo I, desta obra, ele tratou do pecado original e o apresentou como fonte da vida carnal e causa da divisão entre dois tipos de cidades, tendo-se em vista a finalidade na condução da vida humana. 0 pecado e suas conseqüências são apresentados por Agostinho com ênfase em dois pontos: o primeiro, que a carne não poderia ser considerada como um mal em si mesma, mas que decorria da corrupção da alma sua própria corrupção. Em segundo lugar, ele reforçou o laço genético e hereditário decorrente do

\footnotetext{
11 GILSON, Étienne. Evolução da cidade de Deus. São Paulo: Editora Herder, 1965, p. 36 e seguintes.

12 GUERREAU, JALABERT, Anita. Caritas y don en la sociedad medieval occidental. Hispania, LX/1, 204, 2000, p. 34.

${ }^{13}$ GILSON, Étienne. Evolução da cidade de Deus. São Paulo: Editora Herder, 1965, p. 36 e seguintes.
} 
pecado, que fazia com que os homens tivessem pecado em Adão e não através dele. Esta questão teria sido um dos pontos centrais de discordância entre Agostinho e Pelágio e também teve suas conseqüências na diferenciação com a postura dos padres capadócios. O pecado, por ter degradado a natureza humana, teria introduzido uma corrupção definitiva na liberdade de escolha moral humana. A partir de então, os descendentes adâmicos seriam impulsionados constante e mesmo involuntariamente ao pecado:

\begin{abstract}
Já nos livros anteriores apontamos que Deus, para unificar o gênero humano, não apenas pela semelhança de natureza, mas também por laços de consanguinidade, para ligá-los, digo, com o vínculo da paz em unidade concorde, quis procedessem de um só todos os homens. Ademais, foi também vontade sua não estivesse o gênero humano sujeito à morte individual, caso os dois primeiros homens, dos quais um foi criado do nado e do primeiro o outro, por causa da desobediência, não se tornassem credores dela. Foi tão enorme o pecado em que consentiram, que, em virtude dele, a natureza humana piorou e se transmitem aos descendentes o próprio pecado e a necessidade da morte (SANTO AGOSTINHO. 2003, p. 131).
\end{abstract}

Paul Ricoeur dedicou um estudo à significação do pecado original enquanto símbolo e conceito para demonstrar as aporias nas quais o bispo de Hipona chegou com sua conceitualização ${ }^{14}$. Segundo ele, o conteúdo veiculado pelo pecado original escaparia à capacidade de conceituação e somente seria revelado por meio da simbologia do mal. É para comprovar sua tese que Paul Ricoeur desconstrói a conceituação agostiniana, não sem antes a apresentar. A formulação do conceito de pecado original teria sido derivada de uma necessidade polêmica e apologética do cristianismo frente aos gnósticos. Disto resultara a afirmação de que o mal não era ser, não tinha natureza, mas era um não-ser, um nada que decorria da liberdade humana e que, portanto, não era ao homem imposto desde a exterioridade. Segundo Paul Ricoeur, foi com unanimidade que os pais gregos e latinos repetiram sem cessar que o mal não era matéria e não era em si, mas provinha do próprio homem. Dentre eles, foi Agostinho quem defendeu o nada ( $a d$ non esse) do mal e the caracterizou como deficiência (defectus). Com isto, segundo Ricoeur, ele teria chegado próximo de postular uma quase-natureza do mal, na medida em que the deu

\footnotetext{
${ }^{14}$ RICOEUR, Paul. "Le 'péche original' étude de signification. Le conflit des interprétations: essais d'herméneutique.
} Paris: Éditions du Seuil, 1969. 
um caráter ao mesmo tempo hereditário-genético e individual-culpável ${ }^{15}$. Nesta concepção de pecado original, Agostinho teria chegado à consideração de que os homens poderiam ter assegurado somente a perdição, uma vez que esta Ihes havia sido imputada por direito de herança, enquanto eleição e salvação estariam resguardadas nos desígnios insondáveis de Deus ${ }^{16}$.

Elaine Pagels ${ }^{17}$, por outro lado, no intuito de descobrir as razões históricas desta mudança na perspectiva agostiniana, levou adiante uma leitura política da interpretação que vigorou entre os pais da lgreja, desde o século II até o IV, acerca dos três primeiros livros do Genesis. A autora também identificou que com Agostinho houve a ênfase na submissão, face à leitura de liberdade que preponderara até João Crisóstomo. Segundo ela, para João Crisóstomo o Estado não era visto como um espaço de concórdia, justiça e liberdade, mas como força e compulsão, usadas para violar a justiça e para suprimir a liberdade. Ainda que o sistema imperial preservasse a ordem social, o fazia mediante a produção de injustiça, desigualdade e imoralidade. A diferença entre o governo da Igreja e o romano estava no fato de que aquele, ainda que estruturado sobre uma base hierárquica, refletia a harmonia original do Paraíso e garantia a igualdade entre os homens, própria da condição de criatura. Agostinho, em contrapartida, teria vivido um momento de licitude do cristianismo. Segundo a autora, no século $V$, os tempos de perseguições não eram mais do que lembranças, já que com Constantino e Teodósio, o cristianismo passara a ser favorecido e consolidara sua posição como religião oficial do Império. Os bispos que antes eram taxados, presos, torturados e executados, passaram a receber isenções, presentes do tesouro imperial, prestígio e influência na corte. Agostinho teria escrito então, em um momento no qual os cristãos eram livres pra seguirem sua fé e neste sentido, ao defender a degeneração humana e a servidão que obrigava os homens a serem submissos, ele teria justificado a obediência a leis que passaram a ser

\footnotetext{
15 É neste aspecto que Paul Ricouer situa a aporia do conceito de pecado ao mesmo tempo em que afirma que ao lidar com a gnose e com a necessidade de lhe combater, Agostinho formulou um conceito quase-gnóstico do mal.

16 "De uma parte, o argumento jurídico não cessa de se comprimir e de se endurecer: a inculpação em massa da humanidade é a justificativa de Deus. A preocupação da coerência impele a dizer que já que o pecado é sempre voluntário - senão Mani está com a razão - é necessário que nossa vontade, antes de seu próprio exercício, seja implicada em uma vontade malvada de Adão". RICOEUR, Paul. "Le 'péche original' étude de signification. Le conflit des interprétations: essais d'herméneutique. Paris: Éditions du Seuil, 1969, p. 276.

17 PAGELS, Elaine. Adam, Eve and the serpent. New York: Vintage Books, 1988.
} 
promulgadas por Imperadores cristãos e teria fornecido a própria fundamentação para a existência de um governo externo. Ainda que Elaine Pagels desenvolva uma leitura política importante acerca de interpretações exegéticas, temos que também João Crisóstomo viveu no período de licitude do cristianismo e foi destituído de seu cargo episcopal devido ao conflito que travou, não com pagãos, mas com um cristão do porte do bispo de Alexandria, Teófilo. Por outro lado, as reflexões agostinianas sobre o comando e a situação política do Império, conforme já afirmado, foram decorrentes de controvérsias com os pagãos. Ainda que houvesse no período um clima favorável ao cristianismo, este estava muito longe de possuir uma homogeneidade quer interna, quer externamente. Assim, a compreensão da mudança de enfoque agostiniana talvez devesse ser buscada em outra direção. Infelizmente, ainda não dispomos de respostas para levar tal questão adiante.

Temos então, que o conceito de pecado original, que se encontra na raiz das considerações de nossos autores sobre a ausência de poder do homem, contou com dois momentos crucias de elaboração. O primeiro, decorrente da disputa com os gnósticos entre os séculos II e III, resultou na afirmação tanto da liberdade humana baseada na semelhança imagética com Deus, quanto situou nesta liberdade a fonte do mal no mundo para tirar dele sua ontologia. Este debate havia sido recebido por Agostinho, que o levara a extremos interpretativos face à intensificação de seu debate contra Pelágio e Juliano de Éclano entre 412 e 418, autores que, segundo Senellart ${ }^{18}$ e Pagels, teriam, curiosamente, levado adiante a defesa da liberdade humana, apoiados nesta tradição que se constituíra contra a gnose. Agostinho partira desta mesma tradição, mas a teria modificado e a invertido consideravelmente ao acentuar a incapacidade humana de ser livre, tendo em vista a universalidade do pecado, a corrupção da vontade e da carne em virtude de sua hereditariedade e a necessidade de se garantir uma culpabilidade individual paralelamente à genética do mal. Se o mal está no mundo antes do homem, não por meio de

18 "Convencido de que a remissão dos pecados pelo batismo significava para o cristão, se 0 quisesse, a possibilidade de recuperar sua plena liberdade de ação, convencido de que ela lhe permitia, portanto, sempre escolher entre o bem e o mal e realizar sem coerção a lei divina, Pelágio, transpondo para o cristianismo o ideal ético estóico, exaltava a aptidão natural do homem à autonomia. Não é em virtude de uma eleição especial, mas por natureza, que os homens eram capazes de impecantia - viver sem pecado. Bastava um esforço de vontade para restabelecer no presente a inocência pura de Adão e Eva". SENELLART, Michel. As artes de governar. São Paulo: Editora 34, 2006, p. 79. 
uma substância e sim pela deficiência proveniente da vontade humana, esta, individualmente situada é a responsável pela sua perpetuação. Sabemos que o posicionamento agostiniano foi aquele que prevaleceu historicamente, enquanto Pelágio e seus companheiros foram condenados pelos concílios de Cartago.

Por outro lado, o livro XIX desta mesma obra de Agostinho é aquele no qual o autor expôs concepções ético-políticas fundamentais. Nele, o autor dialogou com um dos mais destacados autores romanos para a construção da noção de justiça e direito romanos. No livro III de $A$ República ${ }^{19}$, Cícero apresentara uma discussão sobre a importância da justiça para a expansão do Estado e para o fortalecimento da República como a melhor forma de governo. Para se chegar a esta conclusão, há, a princípio, o uso do contraditório e da exposição da tese de que somente a injustiça é capaz de levar adiante o Estado, tendo em vista que a virtude da justiça prescreve o respeito aos bens privados, a atenção ao gênero humano e a preservação das coisas alheias, públicas e sagradas. Se este preceito fosse seriamente respeitado, toda comunidade política que se expandisse deveria ter como meta a devolução daquilo que conquistou e isto inviabilizaria sua expansão. Filão é quem faz a defesa da injustiça ${ }^{20}$ e sua argumentação parte do princípio de que não há justiça que seja natural. Isto porque a lei é tão diversa quanto são as comunidades políticas constituídas em diferentes regiões e temporalidades. Portanto, não há como se atribuir certa universalidade à justiça ${ }^{21}$, já que o natural é universal, ou seja, deve ser sempre o mesmo em toda parte, e o que se observa no campo da justiça é o predomínio da relatividade. É neste sentido que Filão questiona seus ouvintes:

Se fosse inata a justiça, todos os homens sancionariam o nosso direito, que seria igual para todos, e não utilizariam os benefícios de

\footnotetext{
19 CÍCERO. Da República. São Paulo: Ediouro, sld.

20 "Filão: - Na verdade, me confere uma empresa pouco simpática, pretendendo tornar-me defensor da injustiça! Lélio: - Temerás certamente que, ao dizer tudo quanto se costuma dizer contra a justiça, pareça que defendes tua opinião, quando és brilhante exemplo de honra e probidade; mas, ninguém ignora o hábito de discutir teses contrárias, para chegar ao descobrimento da verdade por esse meio. Filão: - Pois bem, defenderei o mal, em vosso obséquio. Se os que procuram o ouro, não hesitam em afundar-se na lama, nós, que procuramos alguma coisa mais do que o ouro, a justiça, não devemos evitar nenhum incômodo". CíCERO. Da República. São Paulo: Ediouro, sld, p. 91.

21 "Filão: - O direito que procuramos pode ser alguma vez civil, natural nunca: se o fosse, como o quente e o frio, 0 amargo e o doce, seriam o justo e o injusto iguais para todos". CíCERO. Da República. São Paulo: Ediouro, sld, p. 92.
} 
outros em outros tempos nem em outros países. Pergunto, pois: se o homem justo e bom deve obedecer às leis, a quais deve obedecer? Não será a todas sem distinção, porque a virtude não admite essa inconstância, nem a natureza essa variedade, comprovando-se as leis com a pena e não com a nossa justiça. Não há direito natural e, por conseguinte, não há justos por natureza. (CíCERO. sld, p. 94-95).

A refutação dos argumentos de Filão é feita por Lélio, o defensor da justiça natural e de sua incontestável importância para a formulação das leis e composição da República. Segundo Lélio, a justiça é natural porque está inscrita no coração dos homens e provém da reta razão. Portanto, ela se encontra em conformidade com a organização do universo como um todo uno e faz do homem parte integrante deste universo ordenado. Não há possibilidade de o homem desconhecer esta justiça sem negar a si mesmo o caráter humano, visto que ela é inerente à natureza humana. Portanto, esta justiça só poderia ter um caráter universal e imutável, prescrevendo sempre que o homem se direcionasse para o bem e se afastasse do mal ${ }^{22}$. É neste contexto que Lélio faz referência a Tibério $\mathrm{Graco}^{23}$ e repreende sua atitude de desrespeitar os acordos assinados, concedidos e reconhecidos entre os latinos e seus aliados, ainda que tenha mantido a justiça para seus concidadãos. Afinal, se a justiça é universal, natural e imutável não deveria comportar tal relatividade. Portanto, o reconhecimento de um direito era o ponto central para que fosse respeitado, sem que se levasse em consideração se ele dizia respeito a um latino ou a um aliado. Lélio firmou de maneira estreita o vínculo entre direito positivo e justiça, visto que aquele somente pode ter como fundamento esta justiça natural que estava inscrita no coração dos homens e que provinha da própria razão. O legislador sancionaria, promulgaria e tornaria reconhecida uma lei já conhecida pelos cidadãos. Desta forma, a comunidade

\footnotetext{
22 "A razão reta, conforme à natureza, gravada em todos os corações, imutável, eterna, cuja voz ensina e prescreve o bem, afasta do mal que proíbe e, ora com seus mandados, ora com suas proibições, jamais se dirige inutilmente aos bons, nem fica impotente ante os maus. Essa lei não poder ser contestada, nem derrogada em parte, nem anulada; não podemos ser isentos de seu cumprimento pelo povo nem pelo senado; não há que procurar para ela outro comentador nem intérprete; não é uma lei em Roma e outra em Atenas - uma antes e outra depois, mas uma, sempiterna e imutável, entre todos os povos e me todos os tempos; uno será sempre o seu imperador e mestre, que é Deus, seu inventor, sancionador e publicador, não podendo o homem desconhece-la sem renegar-se a si mesmo, sem despojar-se do seu caráter humano e sem atrair sobre si a mais cruel expiação, embora tenha conseguido evitar todos os outros suplícios". CíCERO. Da República. São Paulo: Ediouro, sld, p. 100.

${ }^{23}$ Segundo Sérgio Cardoso, o debate de Cícero com os Gracos teve origem na tentativa de Caio Graco destituir o governo aristocrático, tendo em vista a instauração de uma democracia. Segundo 0 autor, isto ameaçaria 0 equilibrio da sociedade, na medida em que atentava contra o Senado. CARDOSO, Sérgio. "Que República? Notas sobre a tradição do 'governo misto'. In: BIGNOTO, Newton. Pensar a República. Belo Horizonte: Editora da Universidade Federal de Minas Gerais, 2002, p. 46.
} 
política estaria fundada juridicamente, na medida em que são estes direitos reconhecidos que fornecem o vínculo entre os membros da comunidade. Se houvesse a quebra entre direito e justiça, aquele não poderia ser reconhecido, e não haveria vínculo jurídico fundando a comunidade política e, em última instância, o povo não poderia ser formado. Por fim, a defesa da forma de governo capaz de manter este vínculo jurídico entre os cidadãos, a República, é feita por Cipião ${ }^{24}$. Ela foi considerada uma forma de governo misto, tendo em vista que não se reduzia à monarquia, aristocracia ou democracia, porque, para além de um regime específico de governo, teria como finalidade alcançar o bem comum por meio do respeito aos vínculos jurídicos e do governo sábio.

É sobre tal concepção de República que recai a crítica de Agostinho. $\mathrm{O}$ bispo de Hipona parte da formulação de Cipião de que só existe República onde há povo, já que Res publica é coisa do povo. Este é definido pela comunidade de interesses e de direitos reconhecidos. Ademais, não há direito sem justiça, portanto não pode existir uma República se dela estiver ausente a verdadeira justiça ${ }^{25}$. É ao se concentrar na noção de "verdadeira justiça" e "verdadeiro direito" que Agostinho transforma as perspectivas ciceronianas sobre a noção de República e determina um vínculo de amor ao invés de um vínculo jurídico na constituição do povo. Se o povo só existe enquanto comunidade de direitos reconhecidos e só há direito se houver justiça, então, Roma não teve um povo constituído, pois lhe faltava a fonte da verdadeira justiça. Logo, não pode existir República se não há povo e se o direito é visto como um veículo de manutenção das instituições humanas e de utilidade para os mais fortes ${ }^{26}$.

Para sair deste impasse, Agostinho reformula a concepção de povo, fundando-a não mais no vínculo de direito, mas no amor pelos mesmos

\footnotetext{
24 "Quem podia chamar República - continuou Cipião - ao Estado em que todos estavam oprimidos pela crueldade de um? Não havia vínculos de direito, nem consentimento na sociedade, que é o que constituía o povo". CíCERO. Da República. São Paulo: Ediouro, sld, p. 102.

25 "Se é verdadeira semelhante definição, a república romana nunca existiu, por jamais haver sido coisa do povo, que é a definição de república. Define o povo, dizendo-o sociedade fundada em direitos reconhecidos e sobre a comunidade de interesses. Depois explica o que entende por direitos reconhecidos. E acrescenta que a república não pode ser governada sem justiça. Em conseqüência, onde não há verdadeira justiça não pode existir verdadeiro direito. Como o que se faz com direito se faz justamente, é impossível que se faça com direito o que se faz injustamente". SANTO AGOSTINHO. A cidade de Deus contra os pagãos. Bragança Paulista: Editora Universitária São Francisco, 2003, p. 412.

26 SANTO AGOSTINHO. A cidade de Deus contra os pagãos. Bragança Paulista: Editora Universitária São Francisco, 2003, p. 413.
} 
objetos $^{27}$. É isto que se encontra no capítulo XXIV do livro XIX: "O povo é o conjunto de seres racionais associados pela concorde comunidade de objetos amados"28. Agostinho redefine o conceito de povo, e, portanto, de República, a partir de dois elementos centrais. A existência de um conjunto de seres racionais e a união de comum acordo em torno dos mesmos objetos amados. Portanto, o amor uniria os seres racionais ${ }^{29}$. Tendo em vista que este amor cristão, chamado pelos nossos autores de caridade, é um vínculo que une as pessoas da Trindade entre si e torna possível a união entre os homens e destes com Deus, e já que o amor é determinado pelo seu objeto, não há como rejeitar o amor pelo mundo e pelos objetos terrestres como um mal em si mesmo. O amor pelo mundo deve, na verdade, servir para que o homem se eleve à caridade que é a única forma de posse sem medo de perda. O mundo deve ser, desta forma, usufruído e não fruído, já que a fruição deve ser direcionada unicamente a Deus, porque é neste estar-perto-de que o amor encontra sua plena realização ${ }^{30}$. Esta diferenciação no interior do amor, definida a partir do objeto amado e da consideração diversa de objetos que devem ser usufruídos e fruídos, permite a Agostinho não anular integralmente 0 mundo, nem recusar totalmente os laços terrestres que se formam e se consolidam ${ }^{31}$. Todavia, é ao considerar o amor como o vínculo que forja 0

\footnotetext{
${ }^{27}$ Anita Guerreau-Jalabert afirma que Agostinho inovou ao introduzir amor e amare no campo do vocábulo da caritas, inovação esta que foi incorporada no latim cristão. Agostinho também foi além ao dar ao amor não um sentido absoluto, mas ao determinar que o significado do amor estava dado na relação com o objeto amado. GUERREAU-JALABERT, Anita. Caritas y don en la sociedad medieval occidental. Hipania, LX/1, 204, 2000, p. 39.

28 Ibid, p. 419

29 Hannah Arendt fez um importante trabalho acerca da concepção de amor em Agostinho. Segundo a autora, 0 bispo apresentou uma única forma de amor: 0 amor concebido enquanto desejo. Esta associação entre amor $e$ desejo trouxe inúmeras dificuldades para a concepção agostiniana, que só puderam ser resolvidas na diluição do eu e do próximo no amor ao Criador, portanto, no exercício contínuo da caridade. Todavia, Agostinho reconhecia a possibilidade de que 0 amor enquanto desejo se transformasse em amor pelas criaturas e pelas coisas terrestres, tornando o homem "mundano" e o afastando de sua identidade e de sua garantia de eternidade. Este amor pelo mundo, que se esgotava em si mesmo, era chamado de cobiça, uma forma desvirtuada de amor, mas ainda assim amor. Portanto, nesta estrutura do amor enquanto desejo, temos que o próprio desejo é determinado por seu objeto considerado enquanto um bem em si mesmo. 0 desejo determina e constrói seu objeto, na mesma medida em que é por ele determinado e dele recebe sua direção. ARENDT, Hannah. O conceito de amor em Santo Agostinho. Lisboa: Instituto Piaget, sld.É este o movimento que Agostinho apresenta ao conceber sua definição de povo como o conjunto dos seres racionais, unidos pelo amor aos mesmos objetos. É, portanto, o objeto que determinará a inclinação para o bem ou para o mal, para o bom ou mau povo: "Não obstante, seja qual for seu amor, se não é conjunto de animais desprovidos de razão, mas de seres racionais, ligados pela concorde comunhão de objetos amados, pode, sem absurdo algum, chamar-se povo. Certo que será tanto melhor quanto mais nobres os interesses que os ligam e tanto pior quanto menos nobres". SANTO AGOSTINHO. A cidade de Deus contra os pagãos. Bragança Paulilsta: Editora Universitária São Francisco, 2003, p. 419.

${ }^{30}$ ARENDT, Hannah. O conceito de amor em Santo Agostinho. Lisboa: Instituto Piaget, sld, p. 36-37.

${ }^{31}$ Anita Guerreau-Jalabert aponta a importância desta consideração no pensamento de Agostinho, na medida em que ela permite retomar as relações carnais, dependentes da sexualidade e reprodutoras do pecado original, não
} 
povo, ainda que entendido na dupla possibilidade da cobiça e da caridade, que Agostinho transforma consideravelmente estas mesmas relações e pode, a partir de então, considerar o mundo e as instituições humanas em uma perspectiva mais ampla que não apenas resgata à Roma o seu caráter de República, mas, sobretudo, insere a Ecclesia nestas mesmas relações ${ }^{32}$.

Esta república cristã, então, seria aquela forjada com vínculos de amor e encabeçada por um bispo, cuja função estaria vinculada a fazer com que o amor ao mundo fosse convertido em amor a Deus. Neste sentido, Agostinho alerta para o fato de que os "partidários da justiça" ciceronianos já haviam alegado que a servidão seria vantajosa, tendo em vista que o direito teria como meta conduzir o homem para o bem e afastá-lo do mal. Assim, o direito funcionaria como um mecanismo seguro para conduzir o homem virtuosamente e para auxiliá-lo no controle de paixões, que deveriam estar submetidas à racionalidade. Todavia, tal direito deveria estar em pleno acordo com as leis divinas e com os mandamentos proferidas pela única fonte da "verdadeira justiça". Neste sentido, a função episcopal é definida a partir da noção de servidão, unida ao fato de que, mesmo os bispos não poderiam ter segurança de que possuíam uma moralidade superior que os fizesse capazes de presidir. Diz Agostinho, no capítulo XIX do mesmo livro:

\footnotetext{
'Quem deseja o bispado deseja bom trabalho'. Sua intenção era dar a entender que o episcopado é nome designativo de trabalho, não de dignidade. A palavra é grega e significa que quem está à frente é superintendente de seus subordinados, quer dizer, tem de olhar por eles. Epí significa 'sobre' e skopós, intenção; portanto, podemos traduzir episkopêin por 'superintender'. De acordo com isso, não é bispo quem gosta de presidir, não de ser útil. (SANTO AGOSTINHO, 2003, p. 410$)^{33}$.
}

\footnotetext{
como um mal em si mesmas, mas como passíveis de serem sacralizadas por meio dos vínculos espirituais aos quais se encontram subordinados. GUERREAU-JALABERT, Anita. Caritas y don en la sociedad medieval occidental. Hipania, LX/1, 204, 2000, p. 39.

32 "Por isso, não diríamos que não é povo ou que seu governo não é república, enquanto subsista o conjunto de seres racionais unidos pela comunhão concorde de objetos amados. O que dissemos de tal povo e de tal república tornamo-lo extensivo ao povo de Atenas ou de outras regiões da Grécia, ao do Egito, ao da primeira Babilônia dos assírios, quando nas respectivas repúblicas sustiveram grandes ou pequenos impérios, e ao de qualquer outra nação. Porque, em geral, a cidade dos ímpios, refratária às ordens de Deus, que proíbe sacrificar a outros deuses afora Ele, e, por isso, incapaz de fazer a alma prevalecer sobre o corpo e a razão sobre os vícios, desconhece a verdadeira justiça". SANTO AGOSTINHO. "Livro XIX". Cap XXIV. A cidade de Deus contra os pagãos. Bragança Paulista: Editora Universitária São Francisco, 2003, p. 419.

${ }^{33}$ A idéia apresentada nessa passagem sobre o episcopado é a de que o bispo assume tal função em razão do trabalho a ser executado e não devido à dignidade e à honra que o título poderia lhe conferir, tal qual confirmado na análise da edição portuguesa da obra, feita pela Calouste Gulbekian.
} 
Ao bispo é dada a possibilidade de "superintender" ou de "presidir" porque ele próprio encontra-se subordinado ao Criador e porque reconhece que seu poder não decorre de si ou da dignidade de seu cargo, mas provém daquele que o criou. É a preservação da relação com o Criador e a descoberta de que o homem não passa de criatura que transformam a consideração sobre a função pública e política do governo sobre muitos. É somente da autoridade que o homem poderia, então, derivar a superintendência sobre outros ${ }^{34}$. O bispo parece ser aquele que unia, então, de maneira perfeita a vida ativa e a contemplativa na medida em que suas atividades junto à comunidade estavam respaldadas no conhecimento da e na investigação sobre a Verdade. Novamente aqui, a superintendência deriva de um re-conhecimento da autoridade, possibilitado pela contemplação que torna possível a aproximação com aquilo que foi determinado e apresentado nas Escrituras. Parece ser este o sentido das palavras de Agostinho que precedem sua definição da função episcopal:

\begin{abstract}
Ninguém deve, com efeito, entregar-se de tal maneira ao ócio, que se esqueça de ser útil ao próximo, nem de tal maneira à ação, que se esqueça da contemplação de Deus. No ócio não se deve amar a inação, mas a busca e encontro da verdade, a fim de cada qual progredir em tal conhecimento e não invejar ninguém. Na ação não se devem amar a honra ou o poderia nesta vida, porque tudo quanto há sob o sol é vaidade, mas o trabalho em si mesmo, se se propõe a justiça e a utilidade, quer dizer, a incolumidade dos que nos estão subordinados segundo Deus (SANTO AGOSTINHO, 2003, p. 410).
\end{abstract}

Ainda que parta da definição paulina sobre o ofício episcopal, Agostinho também modifica a consideração de Paulo ao retirar dos bispos sua excelência moral como prerrogativa para o exercício de sua função. Se na Primeira Epístola a Timóteo 3,1-13, observamos a união estreita entre exercício de poder e controle moral sobre $\mathrm{si}^{35}$, em Agostinho estes dois elementos

\footnotetext{
34 "Só há caridade bem sucedida aceitando o socorro do Criador, daquele que dá o poder (dator potestatum) para cumprir a lei, pois é apenas na graça divina aceite que é verdadeiramente efetuado o desprendimento do mundo", pois "A deficiência (fraqueza) da criatura face à lei não consiste numa falta de vontade [...] mas numa falta de poder (potestas). A experiência da insuficiência é a da separação entre querer e poder. Em Deus, poder e querer coincidem, a separação é o signo (signum) do estado de criatura que não tem no seu poder o seu próprio ser". ARENDT, Hannah. O conceito de amor em Santo Agostinho. Lisboa: Instituto Piaget, sld, p. 111 e 107, respectivamente.

35 "Se alguém aspira ao episcopado, boa obra deseja. É preciso, porém, que o epíscopo seja irrepreensível, esposo de uma única mulher, sóbrio, cheio de bom senso, simples no vestir, hospitaleiro, competente no ensino, nem dado ao vinho, nem briguento, mas indulgente, pacífico, desinteresseiro. Que ele saiba governar bem sua própria casa, mantendo os seus filhos na submissão, como toda a dignidade. Pois se alguém não sabe governar bem a própria casa, como cuidará da Igreja de Deus? Que ele não seja um recém-convertido, a fim de que não se ensoberbeça e
} 
desvinculam-se completamente, na medida em que esta "excelência moral" é transferida de seus membros para a objetivamente da Ecclesia, enquanto instituição que participa da Cidade de Deus, mesmo situando-se no mundo. Tal fato pode ser explicado por duas questões. Em primeiro lugar, pelas controvérsias travadas por Agostinho contra os donatistas no Norte da África. Posteriormente, pelo posicionamento a favor da graça, da predestinação e da insuficiência humana para ter autonomia e ser capaz de, pela sua própria iniciativa e racionalidade, suplantar sua condição pecadora. Este posicionamento foi por ele adotado ao longo da disputa com os seguidores de Pelágio, conforme já explicitados a propósito do livro XIV.

Segundo Conrad Leyser, o bispo de Hipona reforçou, no final de sua vida, seu desencantamento com a vida em comunidade e determinou que mesmo aqueles que detinham o poder e estavam à frente das comunidades não poderiam ter assegurado o que possuíam. Aos bispos e abades restava, unicamente, a certeza da responsabilidade pelos pecados daqueles colocados sob sua vigilância, mas eles jamais saberiam se estavam levando a mensagem correta para seu rebanho. Da mesma forma, os homens não poderiam saber quem seria escolhido por Deus ${ }^{36}$. Um exemplo claro disto poderia ser buscado na trajetória de Paulo que, de perseguidor de cristãos, tornou-se um dos divulgadores mais sublimes das palavras de Deus. Isto porque, além de se expressar em uma linguagem insuficiente e incapaz de dar conta da totalidade da mensagem divina, o homem era, por descendência, um pecador. Todavia, quando formulou sua filosofia da história cristã. Agostinho refletiu sobre as condições possíveis para a realização de uma comunidade humana em sentido largo. Na obra $A$ cidade de Deus contra os pagãos, ele inseriu a lgreja nas relações humanas, na mesma medida em que transformou consideravelmente a concepção sobre o poder e a função pública a partir da reflexão sobre o episcopado.

incorra na condenação que cabe ao diabo. Além disso, é preciso que os de fora lhe dêem um bom testemunho, para não cair no descrédito e nos laços do diabo". PAULO. "Primeira Epístola a Timóteo". Bíblia de Jerusalém. São Paulo: Editora Paulus, 1985.

${ }^{36}$ LEYSER, Conrad. Authority and ascetism from Augustine to Gregory the Great. Oxford: Clarendon Press, 2000, p. 28. 
Tendo em vista que o povo pode ser conhecido a partir do objeto de seu amor, Agostinho apresentou no capítulo XVII do livro XIX as duas cidades ${ }^{37}$ possíveis para o exercício da caridade ou da cobiça: a cidade terrestre e a de Deus, ou, cidade celeste, conforme visto. Estas reflexões desenvolvidas pelo bispo em Hipona em sua obra, já haviam aparecido, ainda que sob outras designações, em seu comentário sobre o Sermão da Montanha, escrito em 393 e apresentada pelo próprio Agostinho como "a regra perfeita da vida cristã"38. Há somente uma cidade verdadeira porque somente nela há verdadeira justiça tendo em vista que nela Cristo é o chefe. A Cidade de Deus é definida como aquela que tem sua finalidade nas coisas que são eternas, imutáveis e verdadeiras, e que usa as coisas terrestres para atingir aquele objeto amado ${ }^{39}$. Ela é composta por homens que vivem da fé e da esperança na fruição dos bens eternos situados no futuro ${ }^{40}$. Este "reino dos céus" somente pode ser conquistado com o exercício da humildade, da mansidão e do pacifismo e está assentado na unidade: um só Deus, no qual reside os "preceitos maiores de justiça" ${ }^{41}$. A Cidade Terrestre é aquela, portanto, que recebeu os "preceitos menores de justiça" e que é composta por homens que não vivem da fé, mas aspiram à paz terrena tomada como um bem em si mesmo. Estes homens encontravam-se vinculados às relações de mando e obediência e tinham como objeto de seu amor unicamente os bens, as glórias e as comodidades da vida temporal. Ao exercitarem a cobiça, estes homens recaíam em soberba e se tornavam sujeitos à transitoriedade, à variedade, à multiplicidade e à mutabilidade, como pode ser comprovado, por exemplo, pelo culto prestado a vários "falsos" deuses. Estes homens que se mantinham unidos pelo amor às

\footnotetext{
${ }^{37}$ Étienne Gilson defende que em Agostinho "cidade" possível um sentido social e está vinculado à concepção pagã de cidade enquanto corpo político e social no qual domina a noção de justiça como preliminar à existência da cidade. GILSON, Étienne. Evolução da cidade de Deus. São Paulo: Editora Herder, 1965, p. 43. Esta concepção da cidade enquanto vida social é apresentada por Agostinho no capítulo XVII do livro XIX de sua obra. SANTO AGOSTINHO. A cidade de Deus contra os pagãos. Bragança Paulista: Editora Universitária São Francisco, 2003, p. 409.

38 SANTO AGOSTINHO. Livro Primeiro. Sobre o sermão do senhor na montanha. Campo Grande/Rio de Janeiro: Edições Santo Tomás, 2003, p. 51.

39 SANTO AGOSTINHO. A cidade de Deus contra os pagãos. Bragança Paulista: Editora Universitária São Francisco, 2003, p. 408.

40 No capítulo IV do livro XIX Agostinho já retomara a consideração de que "'O justo vive da fé', porque, como ainda não vemos nosso bem, é preciso que o busquemos pela fé. 0 próprio bem-viver não 0 obtemos com nossas próprias forças, se quem nos deu a fé, que nos leva a crer em nossa debilidade, não nos auxilia a crer e a suplicar". SANTO AGOSTINHO. A cidade de Deus contra os pagãos. Bragança Paulista: Editora Universitária São Francisco, 2003, p. 388.

${ }^{41}$ SANTO AGOSTINHO. Livro Primeiro. Sobre o sermão do senhor na montanha. Campo Grande/Rio de Janeiro: Edições Santo Tomás, 2003, p. 51.
} 
coisas terrestres viviam em constante temor. Um temor decorrente da perda da fruição dos objetos terrestres.

Entre a Cidade de Deus e a Cidade Terrestre, situava-se a Igreja, inserida aqui como uma terceira categoria. Isto porque ela não era ainda a fruição plena de Deus e tampouco era o cultivo dos bens terrestres. A Igreja tornava-se, na reflexão de Agostinho, uma instituição que retirava suas forças da participação na Cidade Celeste e identificava-se com o amor pelos bens eternos, na medida em que tinha como prerrogativas a contemplação e o reconhecimento dos ensinamentos de Deus, bem como o alcance da vida feliz por meio da fé e da esperança. Todavia, ela se situava, ainda, no mundo e desta forma tinha por meta a ação e a condução de toda a comunidade cristã para a aproximação com Deus a partir de sua rememoração, da adequação dos hábitos humanos e do ajuste do desejo. A partir destes pressupostos, Agostinho inscreveu-se na tradição do pensamento político antigo, mas deu a ele uma reorientação particular ao modificar sensivelmente as determinações não só de Cícero, mas do próprio Paulo. A lgreja se inscrevia no circuito da caridade na medida em que fora fundada pelo próprio Cristo e tinha sua universalidade garantida na difusão da paixão de Cristo. Era a Encarnação que dava o sentido último para a constituição da comunidade de cristãos que era a Ecclesia.

Da mesma forma, uma sociedade humana historicamente determinada, como, por exemplo, o Império Romano, não poderia ser identificado plenamente com a Cidade Terrena. Um governo específico somente seria "terreno" e "mundano" se restringisse sua preocupação à paz terrena como fim último. Isto permitiu a Agostinho mais uma vez resgatar a experiência política vivenciada por ele de qualquer assimilação à cobiça, o que a retiraria, portanto, da possibilidade de salvação. Ao tornar-se cristão, Constantino teria sido capaz de reconduzir o Império Romano a partir de novos pressupostos, considerados, estes sim, verdadeiros. A despeito do que afirmavam os pagãos, Agostinho demonstra de que forma a moralidade cristã, objetivamente considerada, juntamente com as considerações políticas do governo justo e verdadeiro conduzem, inegavelmente, ao bem do Império, à paz terrena e, em última instância, à vida feliz. 
3. Uma nova perspectiva sobre poder e autoridade: João Cassiano e a institucionalização do monacato:

João Cassiano, por sua vez, desenvolve uma reflexão original sobre poder e autoridade. Diferentemente do que irá vigorar no século VI, sobretudo com Gelásio, tal qual salientado por Hannah Arendt ${ }^{42}$, João Cassiano pensa positivamente a autoridade, pois, segundo ele, os homens a podem ter, enquanto que o poder não está na possibilidade de realização humana. Autoridade, em João Cassiano, está relacionada à normatização e ele a formula a partir de dois elementos centrais. Por um lado, a perícia, ou experiência, que o homem pode ter das tradições e das regras dos pais do deserto que, segundo ele, eram as mais viáveis para a condução da vida ascética. Estas tradições compunham, então, o segundo elemento no qual João Cassiano embasava a autoridade, na medida em que tais instituta, de caráter normativo, divino e com antiguidade atestada, haviam passado de gerações a gerações, como uma cadeia ininterrupta, por meio dos mestres aos discípulos. Assim, segundo ele, somente poderia ter acesso e divulgar as instituições dos monges egípcios aqueles que haviam sido nelas treinados. Este fator reafirmava a experiência, ainda que fosse constituído por João Cassiano como um elemento autônomo, independente do indivíduo e centralizado no grupo: o conjunto dos anciãos ${ }^{43}$.

Neste sentido, o uso do termo auctoritas por Cassiano é revelador deste caráter institucional e normativo do qual a autoridade vinha revestida e ele 0 emprega em dois sentidos complementares. Em primeiro lugar, auctoritas é usado para as pessoas que são legitimadas para estabelecerem preceitos que deveriam ser respeitados na comunidade monástica, como Deus, os Apóstolos e os monges egípcios que receberam os ensinamentos e as normas que mantinham unida a comunidade apostólica. Em segundo lugar, auctoritas refere-se ao preceito ele mesmo, a saber, as Escrituras e a interpretação corretamente feita. E, para João Cassiano, teriam condição de fazer tal interpretação da palavra do primeiro auctor os monges que lutavam contra os vícios e tinham como meta a conquista do reino dos céus por meio de um

\footnotetext{
${ }^{42}$ ARENDT, Hannah. "O que é autoridade?" Entre o passado e o futuro. Rio de Janeiro: Perspectiva, 2005.ie

${ }^{43} \mathrm{GOODRICH}$, Richard. Contextualizing Cassian: aristocrats, asceticism, and reformation in fifth-century Gaul. Oxford: Oxford University Press, 2007.
} 
esforço ascético e de obediência aos preceitos e àqueles que os promulgavam, ou seja, à autoridade.

Tal idéia pode ser observada na décima-quarta conferência de João Cassiano, escrita anteriormente a 426. Nela, a exegese e a correta compreensão das Escrituras aparecem como tarefa fundamental do ofício monástico $^{44}$. $\mathrm{O}$ abade Néstoros iniciou a exposição com a apresentação das duas ciências existentes: práticas ou ativas e contemplativas ou teoréticas. A ciência ativa visava a reforma dos modos e a purificação do homem, enquanto a teorética elevava o pensamento à contemplação das coisas divinas, sagradas e invisíveis. A perfeição na ciência ativa poderia ser alcançada por dois meios. O primeiro era o conhecimento da natureza dos vícios e dos métodos para sua cura. O segundo era o discernimento da ordem das virtudes e a adequação da alma a elas.

Adquirida a ciência prática, o homem tornava-se apto a adentrar no universo teorético que também estava dividido em duas partes: a investigação histórica dos eventos narrados na Escritura e a "inteligência espiritual" ou "ciência das Escrituras" propriamente dita. A primeira, chamada doutrinal pelo Apóstolo, dava ao homem o conhecimento dos eventos passados, sem que ele se preocupasse com a descoberta de sentidos não evidentes. A segunda parte comportava os gêneros tropologia, alegoria e anagogia. Com a tropologia tinhase por meta atingir uma explicação moral, capaz de aperfeiçoar a vida e a formação ascéticas. A alegoria era a revelação do sentido espiritual do tema, na medida em que ela possibilitava o acesso àquilo que estava escondido na narrativa histórica e a penetração no mistério da palavra revelada. Finalmente, a anagogia atentava para o transporte do discurso para coisas divinas e futuras.

O acesso às Escrituras não era obtido por meio do orgulho de si mesmo, causado pelo esforço contínuo da leitura e meditação das Escrituras, mas sim pela observação da conduta e dos trabalhos realizados por aqueles que tinham

\footnotetext{
44 JEAN CASSIEN. Conférences. Paris: Cerf, 1959, vol. 2. Também em JEAN CASSIEN. L. II, 5-2. Institutions cénobitiques. Paris: Cerf, 2001. Segundo Robert Markus: "A compreensão das Escrituras tornou-se o objetivo da disciplina monástica e o vértice do progresso espiritual do monge". MARKUS, Robert A. O fim do cristianismo antigo. São Paulo: Paulus, 1997, p. 188. HADOT, Pierre. O que é a filosofia antiga? São Paulo: Loyola, e RICOUER, Paul. 'O problema do duplo sentido: hermenêutica e semântica'. O conflito das interpretações. Rio de Janeiro: Imago, 1978.
} 
condições de ensinar, pelo fato de que também já haviam aplicado estes métodos para se tornarem moralmente aptos. Segundo Néstoros, somente podia ensinar aquele que, em primeiro lugar, tivesse aprendido não através do orgulho da própria condição, mas pela observação dos atos virtuosos da "instituição dos senhores". Néstoros é claro a este respeito em dois momentos específicos. No primeiro, ele diz a Cassiano e Germano:

Com todo seu ardor, se esforcem para possuir o quanto antes a plenitude da ciência prática, quer dizer, moral. Sem ela, a pureza da contemplação, da qual falamos anteriormente, reside fora de nossa apreensão. É somente ela que nos torna perfeitos e não certamente o efeito da palavra de seus mestres, mas a virtude de suas próprias ações ${ }^{45}$.

Na continuação, o abade pede a atenção especial de Cassiano para o fato de que não é a avidez pela leitura das Escrituras que permite a compreensão do sentido das palavras ali expostas, mas sim o silêncio diante dos ensinamentos dos antigos e a aplicação na purificação do coração por meio do ajuste moral:

Recebam os ensinamentos e as decisões de todos os seus anciãos com uma alma atenta, mas com a boca muda; guarde-as com preocupação no coração, e se apressem em Ihes adquirir, antes de se fazer um doutor ${ }^{46}$.

O abade Néstoros enfatizou, portanto, nesta conferência, os elementos já enunciados para a composição da autoridade. Em primeiro lugar, o exercício de ascese e a conduta moralmente ajustada, decorrentes da experiência e da obediência às instituições dos anciãos. Em segundo lugar, o próprio ensinamento dos anciãos e, por fim, Deus, que, ao criar o homem, tornou-se conhecedor das condições, forças e fraquezas de sua criatura.

Essa relação estreita mantida entre autoridade e ascetismo foi apresentada em outros momentos da obra de João Cassiano. No segundo livro de suas Instituições cenobíticas, por exemplo, ele é explícito na afirmação de que só poderia ser abade aquele que, em primeiro lugar, houvesse renunciado

\footnotetext{
45 JEAN CASSIEN. Conl 14-9. Conferénces. Paris: Éditions du Cerf, 1959, vol 2.

${ }^{46}$ Ibid. Conl 14-9.
} 
aos seus bens e não mais se vangloriasse das riquezas deixadas para trás. Em segundo lugar, poderia reger aquele que houvesse aprendido a trilhar o caminho das virtudes por meio da obediência e da submissão da vontade própria aos anciãos. Retomamos aqui a defesa de que, para ser abade, o homem deveria, antes de mais nada, ter adquirido uma conduta virtuosa, somente possível com a sujeição à autoridade dos anciãos.

Por outro lado, o título dado a sua segunda obra e a forma de sua composição também demonstram a importância normativa da autoridade e da tradição no pensamento de Cassiano. Segundo Anne-Marie Vannier ${ }^{47}$, conlatione $^{48}$, termo usado por Cassiano para se referir às palavras dos anciãos, era no latim o que em grego symbolos representava. O símbolo era um resumo, um verbo abreviatum das Escrituras, de uma doutrina, de uma instituição a ser conhecida e obedecida. Podemos acrescentar que, no caso das conferências, havia autoridade porque elas eram proferidas por uma pessoa instruída na disciplina ascética e que não ensinava apenas com palavras, mas com sua própria experiência. As colações eram "símbolos de autoridade" ${ }^{\prime 9}$ porque apresentavam os ensinamentos daqueles que levaram uma vida na virtude e na solidão e que foram capazes de atingir a "ciência das Escrituras".

Assim, temos que, para Cassiano, os homens estavam aptos ao exercício da autoridade, naquilo que ela tinha de normatizadora e geradora de obediência. Poder, em contrapartida, não gozava do mesmo otimismo, uma vez que João Cassiano faz um uso negativo de potestas, indicando uma ausência. Esta decorria do pecado original e de sua transmissão genética, que promovia a dissociação entre vontade e querer. Foi sobre a incapacidade de viver sem pecados, contra a tese dos pelagianos, que João Cassiano escreveu sua conferência XXIII em meados de 428. Nela, o abade Teoné partira da lição

47 Conforme afirma VANNIER, Marie-Annie. "Introduction". In: CASSIEN, Jean. Traité de l'Incarnation contre Nestorius. Paris: Cerf, 1999; VANNIER, Marie-Annie. Le De Incarnatione Domini de Jean Cassien. In: BADILITA, Cristian; JAKAB, Attila. Jean Cassien entre l'Orient et l'Occident. Paris: Poliron/Beauchesne, 2003.

48 Ressaltamos que em 529, o termo conlatione é usado no II Concílio de Orange, na carta enviada pelo Papa Bonifácio a Cesário de Arles que confirmava as disposições conciliares e determinava que estas fossem conhecidas pelos bispos da Gália: "Que tua Fraternidade igualmente, no curso de um colóquio [conlatione] com certos bispos das Gálias, tenha também pensado freqüentemente na fé católica, nós nos alegramos". GAUDEMENT, Jean. Les canons des conciles mérovingiens (VI-VII siècles). Paris: Cerf, 1989, p.179.

49 VANNIER, Marie-Annie. "Introduction". In: CASSIEN, Jean. Traité de l'Incarnation contre Nestorius. Paris: Cerf, 1999. 
apostólica que determinava "Não faço o bem que quero, e faço o mal que odeio", "Mas se faço o que não quero, não sou eu que o faço, mas o pecado que habita em mim". Por fim: "Eu tenho prazer com a lei de Deus segundo o homem interior, mas vejo nos meus membros uma outra lei, que luta contra a lei do meu espírito, e que me torna cativo sob a lei do pecado que está nos meus membros" ${ }^{50}$. O ancião concluiu que ao dizer estas palavras, o Apóstolo não se reportava aos pecadores, mas àqueles que haviam atingido uma condição de amor pela legis Dei e de repulsa pela legis peccati, ainda que esta continuasse a vigorar em seus membros. Tais textos de Paulo não poderiam se referir aos pecadores porque estes não odiavam o mal. Portanto, mesmo os perfeitos, enquanto vivessem na carne, não poderiam não pecar e contemplar a Deus de forma interrupta, porque nenhuma criatura era estável por si mesma e capaz de obter a beatitude da imutabilidade por meio de sua natureza.

É tendo em vista tal deficiência humana para dominar seu próprio ser em razão da dissociação de sua vontade que a distinção entre poder e autoridade feita por Hannah Arendt ${ }^{51}$ e a afirmação de Larry Scanlon ${ }^{52}$ de que na Idade Média quem tinha autoridade não possuía poder devem ser consideradas. Se, segundo Cassiano, o pecado fazia com que o homem não tivesse poder, tal exercício estava, então, resguardado àqueles para quem tal dissociação não existia: Deus, os demônios e os anjos. Por outro lado, estes seres também possuíam poder porque tinham sobre quem o exercer:

\begin{abstract}
... existe uma outra razão para o nome de principado ou de forças no fato que eles [os demônios] exercem sobre os diversos povos a dominação e o império, ou que eles tenham sob si os espíritos e os demônios [...]. Eles não podem, com efeito, serem chamados dominadores, a menos que tenham sobre quem exercer tal poder, nem poder ou principados se não há ninguém sobre quem eles possam reivindicar a preeminência (JEAN CASSIEN. 1959. Conl 8.14).
\end{abstract}

Podemos encontrar o debate sobre o poder em dois momentos da obra de João Cassiano: no livro II das Instituições cenobíticas e na oitava conferência. Conforme já sugerido, no segundo livro das Instituições, Cassiano tratou da função do superior do mosteiro e o fez a partir do uso de quatro

\footnotetext{
50 JEAN CASSIEN. Conl 23-1. Conférences. Paris: Cerf, 1959.

${ }^{51}$ ARENDT, Hannah. "O que é liberdade?". Entre o passado e o futuro. São Paulo: Perspectiva, 2005.

52 SCANLON, Larry. "'Auctoritas' " and 'Potestas': a model of analysis for medieval culture". Narrative, authority and power: the medieval exemplum and the Chaucerian tradition. Cambrigde: Cambrigde University Press, 1994.
} 
termos: potestas, dominatio, regere e dirigere. Potestas e dominatio são usados como sinônimos e não são possíveis ao homem. Ao superior cabe a regência (regere e dirigere) e ele a conseguiria por meio da renúncia aos bens e pelo fato de ter se submetido com obediência a outro ancião, na medida em que a instrução no caminho das virtudes somente poderia ser feita por meio da mortificação da vontade e do temor a Deus, conforme já mencionado. Por fim, poderia reger aquele que reconhecesse a ausência de poder e de domínio sobre si mesmo. Portanto, o comando estava vinculado a um despojamento simultaneamente material e espiritual. Na oitava conferência, esta situação se mantém, mas Cassiano imprime uma inversão. Intitulada Do principado, nela a capacidade de exercer poder (potestas) e dominação (dominatio) foi atribuída aos príncipes (principes) do mal e aos anjos. Da mesma forma que no livro II das Instituições, potestas e dominatio foram considerados termos sinônimos. Diferentemente daquele, ambos são usados afirmativamente.

A partir da análise destas considerações de Cassiano, temos que para ele, autoridade não é sinônimo de dominação, como vimos conceituado por Max Weber. Dominação é sinônima de poder e ambos não são simplesmente opostos à regência, tal qual afirmou Michel Senellart. O que aparece em Cassiano é a afirmação de que quem tem poder, domina, quem não o tem rege ou dirige. É na ausência ou na existência de poder que reside a diferença entre os dois termos e não precisamente em uma distinção de finalidades. Ademais, diferentemente do que irá prevalecer em concílios gauleses do século $\mathrm{VI}$, temos em João Cassiano a afirmação categórica de que ao homem não está ofertada a possibilidade de exercício de poder, em decorrência do pecado impresso na humanidade por Adão. E não podemos esquecer que na obra de João Cassiano, o despojamento - material e espiritual - é valorizado como prerrogativa para a entrada na e regência da comunidade monástica. Ao enfatizar o caminho que deveria ser percorrido por aqueles que tinham como meta a perfeição de coração e de, por isto, conhecerem as normas de Deus, Cassiano reforçou a autoridade e a regência do superior do mosteiro e, com isto contribuiu para a institucionalização do monacato gaulês. Todavia tal institucionalização não negava a existência de uma interioridade e nem a contrapunha à esfera pública. Ao contrário, colocava-a, em certa medida, a 
serviço da construção de laços políticos em uma sociedade que deveria ser obediente e unida pela caridade.

\section{Considerações Finais:}

Percebemos que João Cassiano situou-se, então, entre o posicionamento dos pais gregos, que foram seus formadores, e aquele defendido por Agostinho. Ao criticar a perspectiva pelagiana, ele se aproximou relativamente aos ensinamentos de Agostinho, ainda que seu nome permaneça vinculado à oposição feita ao bispo de Hipona na própria questão acerca da relação entre graça e livre-arbítrio. Dizemos relativa proximidade porque o ponto diferencial de Cassiano em relação a Agostinho está justamente naquilo que ele se aproxima dos pais gregos. Ainda que ele defenda a incapacidade de impecância mesmo para os perfeitos, ele atribui ao homem a possibilidade de se conduzir virtuosamente e de distinguir o bem do mal. Se o pecado trouxe ao homem o conhecimento do mal, ele não o fez esquecer o bem que conhecia ${ }^{53}$. Assim, a diferença entre os dois estava na relação estabelecida entre autoridade e ascetismo ${ }^{54}$. Enquanto Cassiano apostava na possibilidade de que a autoridade se construísse a partir do aperfeiçoamento moral, ou seja, da prática ascética, a ponto de tentar construir bases seguras para a vitória humana sobre os vícios ${ }^{55}$, Agostinho negava tal possibilidade, na medida em que defendia a incapacidade de o homem se conduzir sozinho no processo de elevação moral. Agostinho negava, portanto, que bispos e abades tivessem certeza de que transmitiam a mensagem correta a seu rebanho e de que possuíam uma elevação moral que os autorizava o comando.

A partir da análise das obras destes dois autores, portanto, torna-se legítimo o questionamento dos pressupostos estabelecidos por Max Weber e Hannah Arendt, ou seja, de que houve no período de "queda de Roma" quer uma autoridade legitimada carismaticamente e não por meio de instituições seguras que garantissem a obediência, quer um inchaço do privado face ao estrangulamento do político, em decorrência da importância adquirida pela moralidade e pela interioridade. Ao dar autoridade a bispos e abades e

\footnotetext{
53 Esta questão é objeto da polêmica conferência XIII, considerada pelos estudiosos como o ponta pé inicial à controvérsia semi-pelagianista.

54 LEYSER, Conrad. Authority and ascetism from Augustine to Gregory the Great. Oxford: Clarendon Press, 2000.

55 Toda a segunda parte da obra Instituições cenobíticas é dedicada a esta questão.
} 
incentivar a renúncia aos bens e a partilha de uma vida em comum, nossos dois autores propiciaram um terreno fértil para a existência de uma comunidade regulada por laços políticos, cujo vínculo era a caridade ${ }^{56}$. E se Hannah Arendt estava correta ao afirmar que a Igreja herdou a noção de autoridade romana cujas principais características eram a estreita relação mantida com a tradição e a conformidade com as decisões dos anciãos, fundadores da cidade e da República romana - mas a reformulou ao interpretá-la à luz da herança grega, podemos afirmar então que foi João Cassiano quem consolidou esta passagem, na medida em que estreitou os vínculos entre autoridade e tradição e a tornou prerrogativa para a conduta, a ciência e o exercício da autoridade e não Agostinho, como sugeriu Hannah Arendt ${ }^{57}$.

\section{Referências Bibliográficas:}

Fontes:

1. CÍCERO. "Livro III". Da República. São Paulo: Ediouro, sld.

2. JEAN CASSIEN. Institutions cénobitiques. Paris: Cerf, 2001 (versão bilíngüe latim-francês. Sources chrétiennes).

3. JEAN CASSIEN. Conférences. Paris: Cerf, 1959 (versão bilíngüe latimfrancês. Sources chrétiennes).

4. SANTO AGOSTINHO."Livro XIX". A cidade de Deus contra os pagãos. Bragança Paulista: São Francisco, 2003. Parte II.

5. SANTO AGOSTINHO. "Livro I". Sobre o sermão do senhor na montanha. Campo Grande/Rio de Janeiro: Edições Santo Tomás, 2003.

6. SANTO AGOSTINHO. Confissões. São Paulo: Nova Cultural, 1996.

7. SÃO PAULO. "Primeira Epístola a Timóteo". Bíblia de Jerusalém. São Paulo: Editora Paulus, 1985.

\section{Obras consultadas:}

1. ARENDT, Hannah. O conceito de amor em Santo Agostinho. Lisboa: Instituto Piaget, sld.

2. "O que é liberdade?". Entre o passado e o futuro. São Paulo: Perspectiva, 2005.

3. . "O que é autoridade?". Entre o passado e o futuro. São Paulo: Perspectiva, 2005.

4. . "As esferas pública e privada". A condição humana. Rio de Janeiro: Forense Universitária, 1999.

5. BADILITA, Cristian; JAKAB, Attila. Jean Cassien entre l'Orient et l'Occident. Paris: Poliron/Beauchesne, 2003.

\footnotetext{
${ }^{56}$ Cassiano também explora a caridade como vínculo social em sua conferência XVI.

57 "Essa transformação foi, em larga medida, consumada por Sto. Agostinho, o único grande filósofo que os romanos tiveram, Pois a base de sua filosofia, Sedis animi est in memoria, é precisamente aquela articulação conceitual da experiência especificamente romana que os próprios romanos, avassalados como eram pela Filosofia e pelos conceitos gregos, jamais completaram". ARENDT, Hannah. Entre o passado e o futuro. São Paulo: Perspectiva, 2005, p. 169.
} 
6. BROWN, Peter. Santo Agostinho: uma biografia. Rio de Janeiro: Record, 2005.

7. CARDOSO, Sérgio. Que República? Notas sobre a tradição do 'governo misto'. In: BIGNOTO, Newton (org). Pensar a República. Belo Horizonte: Editora da Universidade de Minas Gerais, 2002.

8. CASIDAY, Augustine. Tradition and theology in St John Cassian. New York: Oxford University Press, 2007.

9. GIDDENS, Anthony. Política, sociologia e teoria social: encontros com o pensamento social clássico contemporâneo. São Paulo: Editora da UNESP, 1998.

10. GILSON, Étienne. Evolução da cidade de Deus. São Paulo: Editora Herder, 1965.

11. GRADOWICS-PANCER, Nira. Enfermement monastique et privation d'autonomie dans lês règles monastiques (V-VI siècle). Revue Historique, 583, t. 288/1, 1992.

12. GUERREAU-JALABERT, Anita. Caritas y don en la sociedad medieval occidental. Hipania, LX/1, 204, 2000, p. 27-62.

13. HADOT, Pierre. O que é a filosofia antiga? São Paulo: Loyola, 2004.

14. HARTOG, François. A história de Homero a Santo Agostinho. Belo Horizonte: Editora da Universidade Federal de Minas Gerais, 2001.

15. LEYSER, Conrad. Authority and ascetism from Augustine to Gregory the Great. Oxford: Clarendon Press, 2000.

16. MARKUS, Robert A. O fim do cristianismo antigo. São Paulo: Paulus, 1997.

17. MOMIGLIANO, Arnaldo et all. El conflicto entre el paganismo y el cristianismo en el siglo IV. Madrid: Alianza, 1989.

18. PAGELS, Elaine. Adam, Eve and the serpent. New York: Vintage Books, 1988.

19. RAMOS, Francisco Manfredo Tomás Ramos. "A Civitas política de Agostinho: uma leitura a partir do Epistolário e do A Cidade de Deus". In: SOUZA, José Antônio de C. R. O reino e o sacerdócio: o pensamento político na Alta Idade Média. Porto Alegre: EDIPUCRS, 1995.

20. RICOEUR, Paul. Le conflit des interprétations: essais d'herméneutique. Paris: Éditions du Seuil, 1969.

21. ROUSSEAU, Philip. Ascetics, authority and the church in the age of Jerome and Cassian. Oxford: Oxford University Press, 1978.

22. SCANLON, Larry. "'Auctoritas' and 'potestas': a model of analysis for medieval culture". Narrative, authority and power. the medieval exemplum and the Chaucerian tradition. Cambridge: Cambridge University Press, 1994.

23. SENELLART, Michel. "A etimologia do nome rei". As artes de governar. São Paulo: Editora 34, 2005.

24. WEBER, Max. Conceitos sociológicos fundamentais. Lisboa: Edições 70, 2005. 